\title{
The larval development of Pinnixa gracilipes Coelho (Decapoda, Pinnotheridae) reared in the laboratory
}

\author{
Jô de F. Lima '; Fernando Abrunhosa ${ }^{1}$ \& Petrônio A. Coelho ${ }^{2}$
}

\begin{abstract}
Núcleo de Estudos Costeiros, Universidade Federal do Pará. Campus de Bragança, Alameda Leandro Ribeiro, Aldeia, 68600-000 Bragança, Pará, Brasil. E-mail: jodeflima@yahoo.com.br; faraujo@ufpa.br

${ }^{2}$ Departamento de Oceanografia, Universidade Federal de Pernambuco. Avenida Arquitetura, Cidade Universitária, 50670-901 Recife, Pernambuco, Brasil. E-mail: petronio.coelho@bol.com.br
\end{abstract}

\begin{abstract}
Pinnixa gracilipes Coelho, 1997 is a small pinnotherid crab living in association with ghost shrimp Lepidophthalmus siriboia Felder \& Rodrigues, 1993 in the northeastern region of Pará State, Brazil. Larvae of $P$. gracilipes were reared in the laboratory from hatching to the megalopa stage. The complete zoeal period averaged 24 days. Mean duration for each larval stage was 5, 4, 4, 5 and 6 days, respectively. In the present study, five zoeal and megalopal stages are described and illustrated in detail. Morphological comparisons with previous reported works on Pinnotheridae larvae are briefly discussed.
\end{abstract}

KEY WORDS. Larval description; pinnotherid crab.

RESUMO. O desenvolvimento larval de Pinnixa gracilipes Coelho (Decapoda, Pinnotheridae) cultivado em laboratório. Pinnixa gracilipes Coelho, 1997 é um pequeno caranguejo pinoterídeo que vive em associação com Lepidophthalmus siriboia Felder \& Rodrigues, 1993 no nordeste do Estado do Pará, Brasil. Larvas de P. gracilipes foram cultivadas em laboratório desde o nascimento ao estágio megalopa. $O$ desenvolvimento completo durou cerca de 24 dias. $O$ período médio de cada estágio foi 5, 4, 4, 5 e 6 dias, respectivamente. No presente trabalho, os cinco estágios zoeae e megalopa são descritos e ilustrados em detalhes. Comparações morfológicas com estudos anteriores sobre larvas da família Pinnotheridae são brevemente discutidas.

PALAVRAS-CHAVE. Caranguejo pinoterídeo; descrição larval.

The literature have reported a lot of works on ecology and systematic of adults of the Pinnotheridae family (Grove \& Woodin 1996, Alves \& Pezzuto 1997, 1998, Campos 2002). However few studies are concerned on the morphological descriptions of larval stages. Actually, most studies are concentrated in the genera Pinnixa White, 1846, Tunicotheres Campos, 1996 and Dissodactylus Smith, 1870 (Faxon 1879, Sexiguchi 1978, Bousquette 1980, Marques \& Pohle 1996a, b). Only two works on larval descriptions have been reported: P. rathbuni Sakai (SEKIGUCHI 1978) and P. longipes (Lockington, 1877) (BousquetTe 1980).

Coelho (1997), after meticulous revision of the genus Pinnixa, listed for Brazil nine species among which three were registed as new species: P. latissima Coelho, 1997, P. leptodactyla Coelho, 1997 and P. gracilipes Coelho, 1997. Recently, three of these species were moved to for the genus Austinixa Heard \& Manning, 1997: A. aidae (Righi, 1967), A. patagoniensis (Rathbun, 1918) and A. leptodactyla Coelho, 1997, remaining only seven species for the genus Pinnixa. No species occurring in Brazil had the complete larval development described.

In the present work, $P$. gracilipes, a small crab ectosymbiont with the thalassinid Lepidophthalmus siriboia
Felder \& Rodrigues, 1993 is described and illustrated in detail from larvae reared in the laboratory. These results are briefly compared with other descriptions previously reported on pinnotherid larvae.

\section{MATERIAL AND METHODS}

Four ovigerous females were obtained from Canela Island, northeast of Para State. The females were conditioned individually in two 5-liters aquariums with constant aeration and filled with marine water.

After hatching, larvae were transferred into glass containers of $500 \mathrm{ml}$ capacity (approx. 30 larvae/container) filled with filtered seawater and exposed to room temperature in the laboratory, approximately $27^{\circ} \mathrm{C}$. Salinity was maintained at $30 \%$ and $\mathrm{pH} 8,2$. Water and food were changed every three days. The larval and postlarval stages were fed with rotifers Brachionus sp. Cultured diatom Thalassiosira sp. was added to the culture.

Exuviae, some zoea larvae and a single megalopa were preserved in ethylic alcohol 70\%+glycerin (1:1) solution. The larvae were dissected with fine needles, measured and illus-

Revista Brasileira de Zoologia 23 (2): 480-489, junho 2006 
trated, under a binocular microscope. The carapace length was the ocular length (OL), which corresponds he distance from the anterior portion of ocular region to the posterodorsal margin of the carapace. All measurements were made with an ocular micrometer.

The terminology used in the description follows SEKIGUCHI (1978), Bousquette (1980), Pereyra Lago (1987, 1989), Marques \& Pohle (1996 a, b) and Magalhães \& Medeiros (1998).

\section{RESULTS}

The larval development of $P$. gracilipes consisted of five zoeal and one megalopal stages. Only one single megalopa was obtained from the larval culture. The Megalopa failed in molting into first crab probably due an inadequate shelter used in the experiment. The intermolting period of each larval stage and survival rate are presented in the table I. The morphological features of the Zoea IV are compared with those previously reported species: P. rathbuni, $P$. longipes and $P$. gracilipes are shown in the table II.

The first stage of $P$. gracilipes is described in detail. Only main morphological changes were described for stages following the first zoea.
Table I. Survival rate, intermolting period and accumulative days of Pinnixa gracilipes reared in the laboratory.

\begin{tabular}{lccc}
\hline Larval stages & $\begin{array}{c}\text { Intermolting } \\
\text { period (days) }\end{array}$ & $\begin{array}{c}\text { Cumulative } \\
\text { (days) }\end{array}$ & $\begin{array}{c}\text { Survival rate } \\
(\%)\end{array}$ \\
\hline Zoea I & 5 & 5 & 70 \\
Zoea II & 4 & 9 & 55 \\
Zoea III & 4 & 13 & 30 \\
Zoea IV & 5 & 18 & 10 \\
Zoea V & 6 & 24 & 3 \\
Megalopa & $*$ & $*$ & 1 \\
\hline
\end{tabular}

*) Not recorded.

\section{Zoea I}

Carapace length (OC): $0.33 \mathrm{~mm}(0.32-0.34 \mathrm{~mm})$.

Carapace (Fig.8): bearing one dorsal, one rostral and two lateral spines. Eyes sessile.

Antennule (Fig. 1): uniramous, unsegmented, smooth and conical with two long and one short terminal aesthetascs.

Antenna (Fig. 2): uniramous, elongate, with a tapered protopodite and two rows of spinules distally and one simple

Table II. Morphological comparisons between features of the zoea IV of P. rathbuni, P. longipes and $P$. gracilipes. (S) Setation, (A) aesthetascs, (Seg) segment, (Exop) exopod, (BE) basal endite, (Bas) basipod, (CE) coxal endite, (End) endopod, (Scap) scaphognathite.

\begin{tabular}{|c|c|c|c|}
\hline Appendages & P. rathbuni (1) & P. longipes (2) & P. gracilipes (3) \\
\hline \multicolumn{4}{|l|}{ Antennule: } \\
\hline End & present as bud & present as bud & present as bud \\
\hline Exop - A & 8 aesthetascs & 6 aesthetascs & 7 aesthetascs \\
\hline Antenna & $\begin{array}{l}\text { protopodite shorter than } \\
\text { endopodite }\end{array}$ & $\begin{array}{l}\text { protopodite longer than } \\
\text { endopodite }\end{array}$ & $\begin{array}{l}\text { protopodite absent and endopodite } \\
\text { reaching medial portion of protopodite }\end{array}$ \\
\hline \multicolumn{4}{|l|}{ Maxillule: } \\
\hline End Seg & 2-segmented & 2-segmented & 2-segmented \\
\hline Protopodite & absent & absent & present \\
\hline $\mathrm{BE}$ & 10 setae & 13 setae & 9 setae \\
\hline CE & 6 setae & 6 setae & 4 setae \\
\hline \multicolumn{4}{|l|}{ Maxilla: } \\
\hline Scap - S & 32 setae & 19 setae & 18 setae \\
\hline End - $S$ & 3 setae & 3 setae & 3 setae \\
\hline$B E-S$ & 18 setae & 14 setae & 12 setae \\
\hline$C E-S$ & 9 setae & 8 setae & 7 setae \\
\hline \multicolumn{4}{|l|}{ Maxilliped I } \\
\hline Exop - S & 12 setae & 9 setae & 10 setae \\
\hline End - $S$ & $2+2+1+2+5$ setae & $2+2+1+2+5$ setae & $2+2+1+2+5$ setae \\
\hline Bas - $\mathrm{S}$ & 9 setae & 10 setae & 11 setae \\
\hline \multicolumn{4}{|l|}{ Maxilliped II } \\
\hline Exop - S & 12 setae & 9 setae & 10 setae \\
\hline End - S & $0+5$ setae & $0+5$ setae & $0+4$ setae \\
\hline Bas - S & 4 setae & 4 setae & 4 setae \\
\hline
\end{tabular}

1) SeKIGUCHI (1978), 2) Bousquette (1980), 3) This work. 


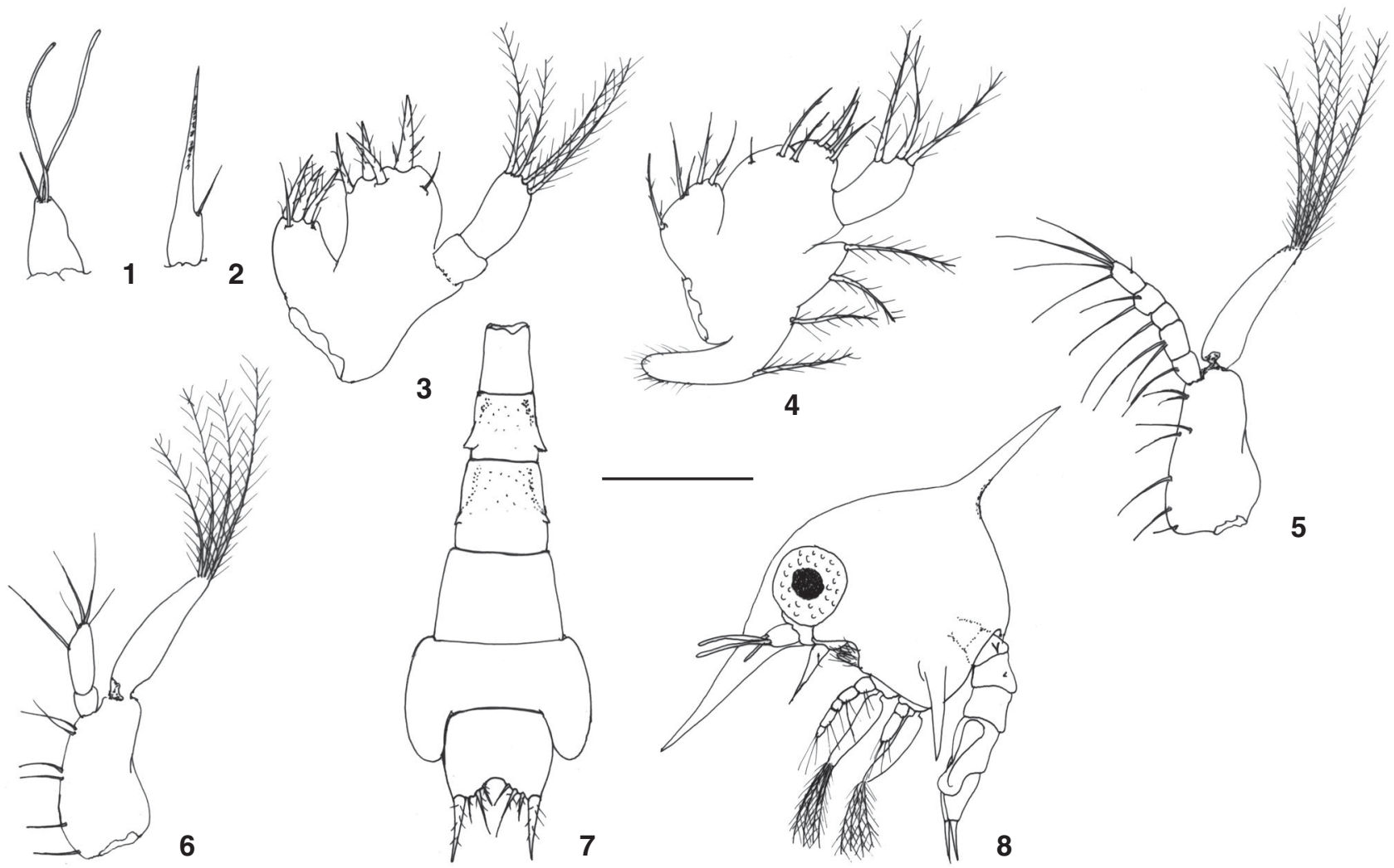

Figures 1-8. Zoea I of Pinnixa gracilipes: (1) antennule; (2) antenna; (3) maxillule; (4) maxilla; (5) first maxilliped; (6) second maxilliped; (7) abdomen and telson; (8) first zoea lateral view. Scale bar: $1-4=0.075 \mathrm{~mm} ; 5-6=0.15 \mathrm{~mm} ; 7=0.2 \mathrm{~mm} ; 8=0.3 \mathrm{~mm}$.

median setae.

Maxillule (Fig. 3): endopodite 2-segmented, distal segment showing four terminal long plumose setae. Basal endite with four plumodenticulate and one simple setae. Coxal endite with three distal plumodenticulate and two marginal small simple setae. Protopodite absent.

Maxilla (Fig. 4): scaphognathite with three to four plumose setae along the anterior margin, tapering to rounded terminal process bearing microtrichia. Endopodite unsegmented with $2+1$ long plumose setae. Basal endite with proximal and distal lobes fused showing five terminal plumodenticulate setae and 1 simple sub terminal seta. Coxal endite with proximal and distal lobes fused with four to five plumose setae.

First Maxilliped (Fig. 5): basipodite with internal margin bearing 2,1,2,2 setae. Endopodite 5-segmented with 2, 2, 1, 2,5 setae, respectively. Exopod unsegmented, with four plumonatatory setae.

Second Maxilliped (Fig. 6): basipodite with five to six setae. Endopodite 2-segmented with 0 and $(4+1)$ setae, respectively. Exopod unsegmented with four plumo-natatory setae.

Abdomen and telson (Fig.7): Abdomen showing 5 abdominal somites; somites 2 and 3 with a pair of acute dorsolat- eral spine projecting anteriorly; somite 5 with lateral extensions, which overlap the telson. Telson bifurcated with two long lateral plumose spines. Internal margin showing $6(3+3)$ plumose setae of diverse sizes.

\section{Zoea II}

Carapace length (OL): $0.42 \mathrm{~mm}$ (0.43-0.44 mm).

Carapace (Fig. 16): similar to previous stage. Eyes stalked. Antennule (Fig. 9): uniramous, unsegmented, smooth and conical with 4 long and one short terminal aesthetascs.

Antenna (Fig. 10): similar to previous stage.

Maxillule (Fig. 11): basal endite shows two additional plumodenticulate setae. Coxal endite with four distal plumodenticulate setae and two small simple basal setae. Protopodite with one long plumose seta.

Maxilla (Fig. 12): scaphognathite with six setae, tapering to delta in shape, terminal process bearing microtrichia. Basal endite with proximal and distal lobes fused showing nine plumodenticulate cuspidate setae. Coxal endite with proximal and distal lobes almost fused with four to five plumose setae and marginal microtrichia.

First Maxilliped (Fig. 13): endopod 5-segmented with 2, 


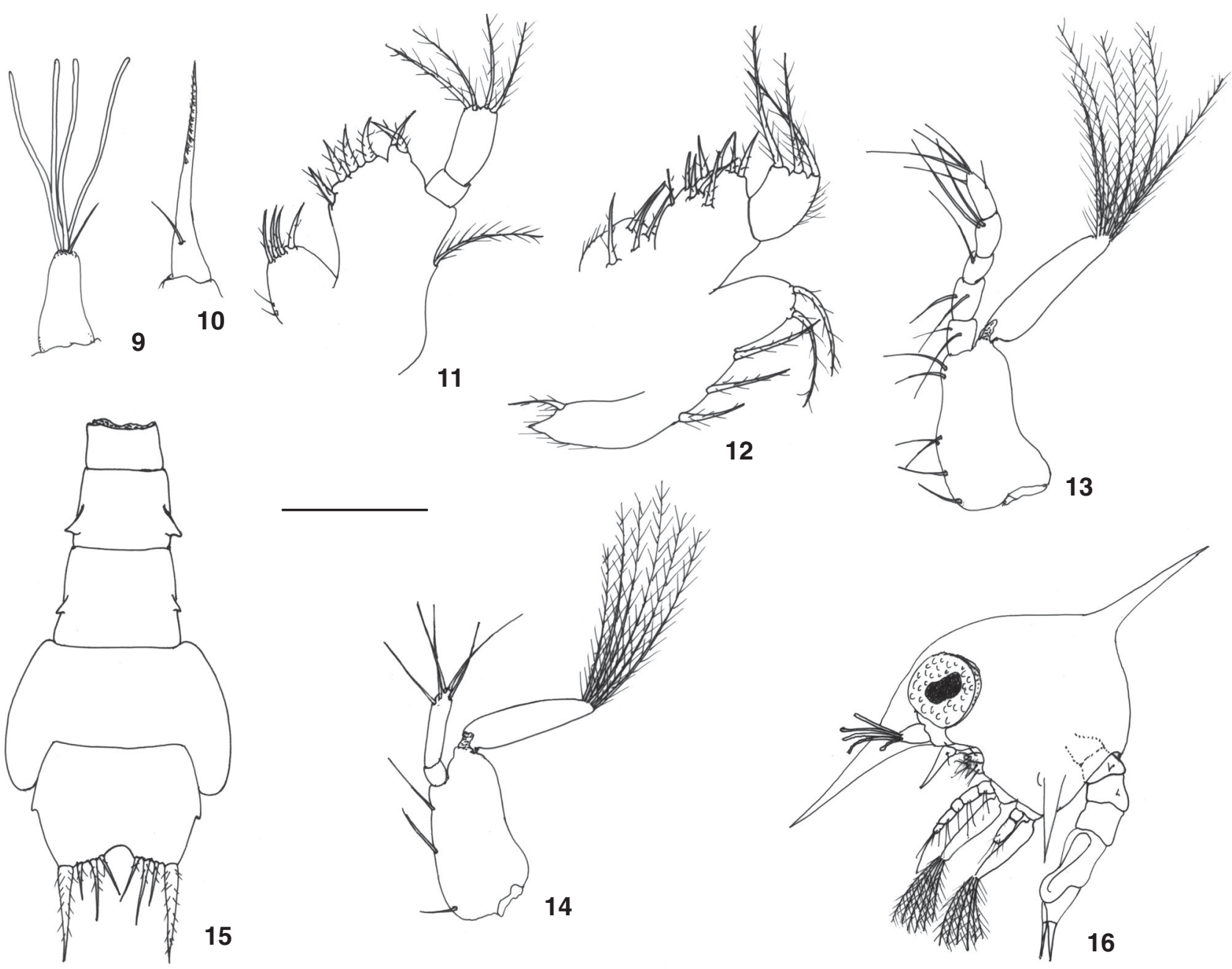

Figures 9-16. Zoea II of Pinnixa gracilipes. (9) antennule; (10) antenna; (11) maxillule; (12) maxilla; (13) first maxilliped; (14) second maxilliped; (15) abdomen and telson; (16) zoea II lateral view. Scale bar: 9-12=0.075 mm; 13-14=0.15 mm; $15=0.2 \mathrm{~mm} ; 16=0.36 \mathrm{~mm}$.

2, 1, 2,(4+1) setae, respectively. Exopodite unsegmented, with six plumo-natatory setae.

Second Maxilliped (Fig. 14): exopodite unsegmented with six plumo-natatory setae.

Abdomen and telson (Fig. 15): abdomen without alteration. External margin of telson with two spines projecting laterally.

\section{Zoea III}

Carapace length (OC): $0.53 \mathrm{~mm}(0.52-0.54 \mathrm{~mm})$.

Carapace (Fig. 24): Similar to previous stage.

Antennule (Fig. 17.): with five long aesthetascs and 1 simple seta.

Antenna (Fig. 18): similar to previous stage.

Maxillule (Fig. 19): basal endite with seven plumodenticulate setae. Protopodite present.

Maxilla (Fig. 20): scaphognathite with 13 plumose setae.
Basal endite with 10 plumodenticulate setae. Coxal endite with proximal and distal lobes almost fused with four to five plumose setae and marginal microtrichia.

First Maxilliped (Fig. 21): basipod with nine simple setae. Exopod with eight plumo-natatory setae.

Second Maxilliped (Fig. 22): exopod with eight plumonatatory setae.

Abdomen and telson (Fig. 23): similar to previous stage.

\section{Zoea IV}

Carapace length (OC): $0.65 \mathrm{~mm}$ (0.64-0.66 mm).

Carapace (Fig. 32): without alteration

Antennule (Fig. 25.): with seven terminal aesthetascs. Endopodite bud.

Antenna (Fig. 26): endopodite bud reaching medial portion of protopodite.

Revista Brasileira de Zoologia 23 (2): 480-489, junho 2006 


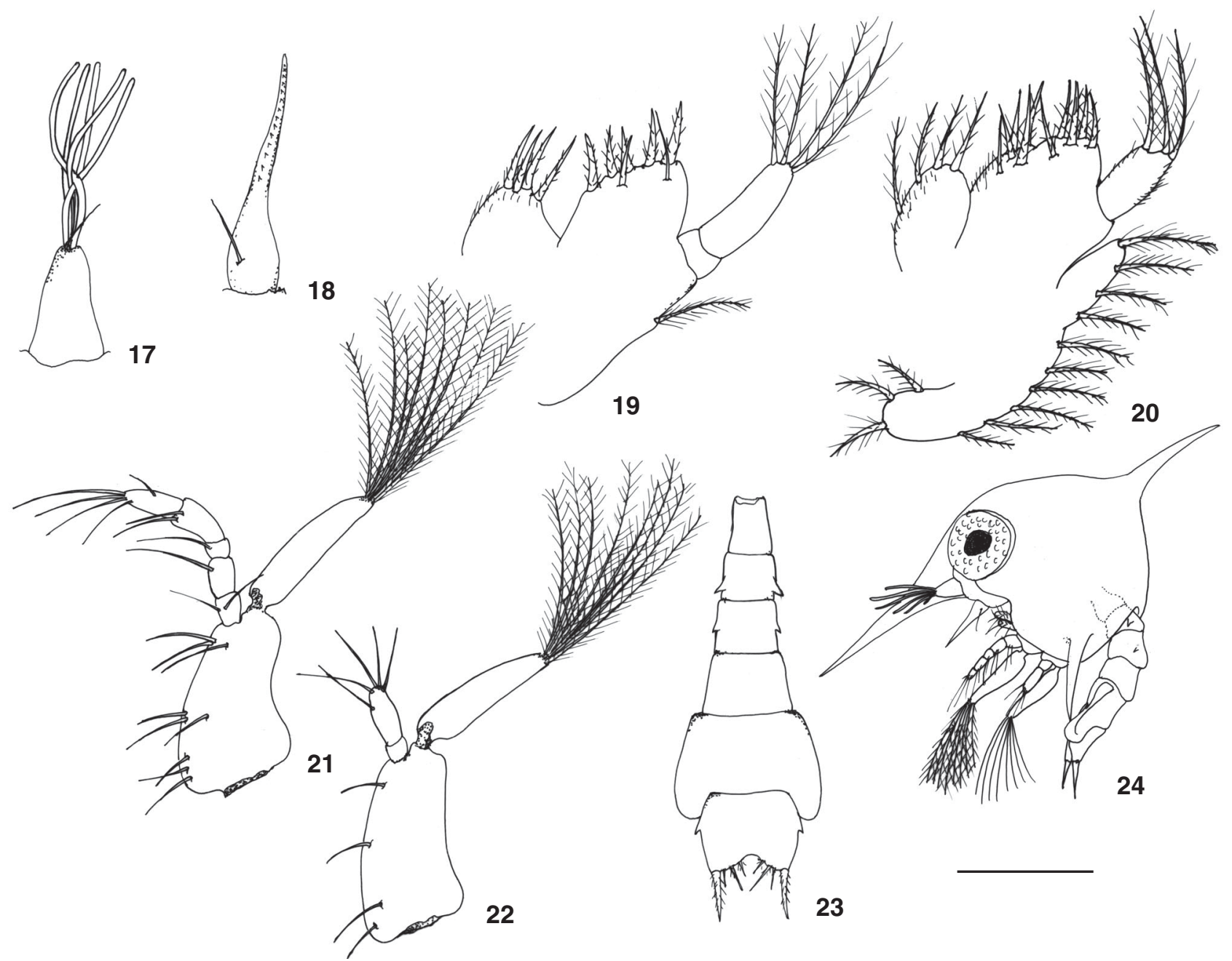

Figures 17-24. Zoea III of Pinnixa gracilipes: (17) antennule; (18) antenna; (19) maxillule; (20) maxilla; (21) first maxilliped; (22) second maxilliped; (23) abdomen and telson; (24) zoea III, lateral view. Scale bar: 17-20=0.85 mm; 21-22=0.15 mm; $23=0.25 \mathrm{~mm} ; 24=0.46 \mathrm{~mm}$.

Maxillule (Fig. 27): basal endite with nine plumodenticulate and 1 simple seta. Protopodite present.

Maxilla (Fig. 28): scaphognathite with 18 plumose setae. Basal endite with 12 to 13 plumodenticulate setae. Coxal endite with seven plumose setae and marginal microtrichia.

First Maxilliped (Fig. 29): basipodite with 11 simple setae. Exopodite with 10 plumo-natatory setae.

Second Maxilliped (Fig. 30): exopodite with 10 plumonatatory setae.

Abdomen and telson (Fig. 31): pleopods buds in the abdominal somites two to five. Telson similar to previous stage.

\section{Zoea V}

Carapace length (OC): $0.76 \mathrm{~mm}(0.75-0.77 \mathrm{~mm})$.

Carapace (Fig. 42): similar to previous stage.

Antennule (Fig. 33.): endopodite with seven terminal aesthetascs. Endopodite bud.

Antenna (Fig. 34): endopodite bud more developed than previous stage with one small basal seta.

Maxillule (Fig. 35): basal endite with 11 plumodenticulate and five simple setae. Coxal endite eight plumose setae.

Maxilla (Fig. 36): scaphognathite with 24 to 26 plumose setae. Basal endite with 18 to 19 plumodenticulate setae. Coxal endite with 11 plumose setae.

First Maxilliped (Fig. 37): similar to previous stage. Second Maxilliped (Fig. 38): similar to previous stage.

Third Maxilliped (Fig. 39): with endopod and exopod visible. Abdomen and telson (Fig. 40): with four pairs of pleopods longer than previous stage, unsegmented and uniramous. Telson similar to previous stage.

Pereiopods (Fig. 41): with five pairs as illustrated. 


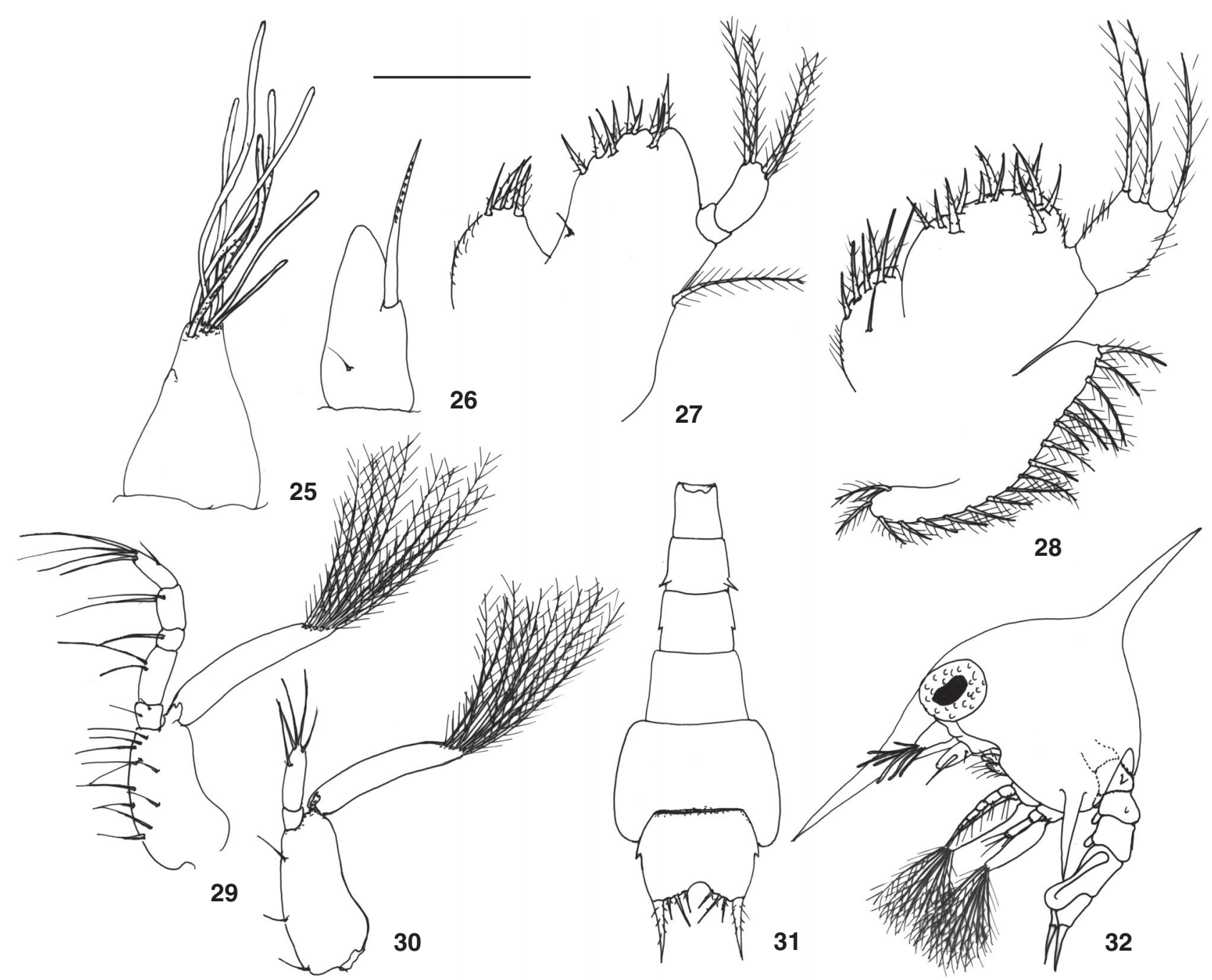

Figures 25-32. Zoea IV of Pinnixa gracilipes: (25) antennule; (26) antenna; (27) maxillule; (28) maxilla; (29) first maxilliped; (30) second maxilliped; (31) abdomen and telson; (32) zoea IV, lateral view. Scale bar: 25-28=0.1 mm; 29-30=0.2 mm; $31=0.3 \mathrm{~mm} ; 32=0.6 \mathrm{~mm}$.

\section{Megalopa}

Carapace length (OC): $1.00 \mathrm{~mm}$.

Carapace (Fig. 51): carapace semi rounded, wider than long, with a triangular rostrum separating the stalked eyes. Eyes deeply lodged in the orbit. The dorsal surface of the carapace is smooth except for the presence of innumerable plumose setae sidelong.

Antennule (Fig. 43): basal segment inflated and lacking setae. Peduncle 2-segmented, distal segment with one simple seta. Endopodite uniramous with two terminal setae. Exopodite 4-segmented with eight aesthetascs and one simple seta.

Antenna (Fig. 44): antennal peduncle 3-segmented, basal and subsequent segments bearing simple setae. Antennal flagellum with 7 -segmented. Segments 5 and 6 with one simple seta. Last segment with three terminal setae.
Maxillule (Fig. 45): protopodite present. Endopod unsegmented, filamentous with two small setae. Basal endite with 17 to 18 plumodenticulate setae. Coxal endite with 10 setae.

Maxilla (Fig. 46): scaphognathite with 41 to 43 plumose setae. Endopodite reduced, lacking setae. Basal endite with numerous setae. coxal endite with 14 setae.

First Maxilliped (Fig. 47): basal and coxal endite with numerous setae. Endopodite 3-segmented with two simple setae in the first segment. Exopodite 2-segmented, proximal and distal segment with two and four simple setae, respectively.

Second Maxilliped (Fig. 48): basal and coxal endites lacking setae. Endopodite 5-segmented, with 0, 3, 0, 11,9 setae, respectively. Exopod 2-segmented, distal segment with five setae.

Revista Brasileira de Zoologia 23 (2): 480-489, junho 2006 


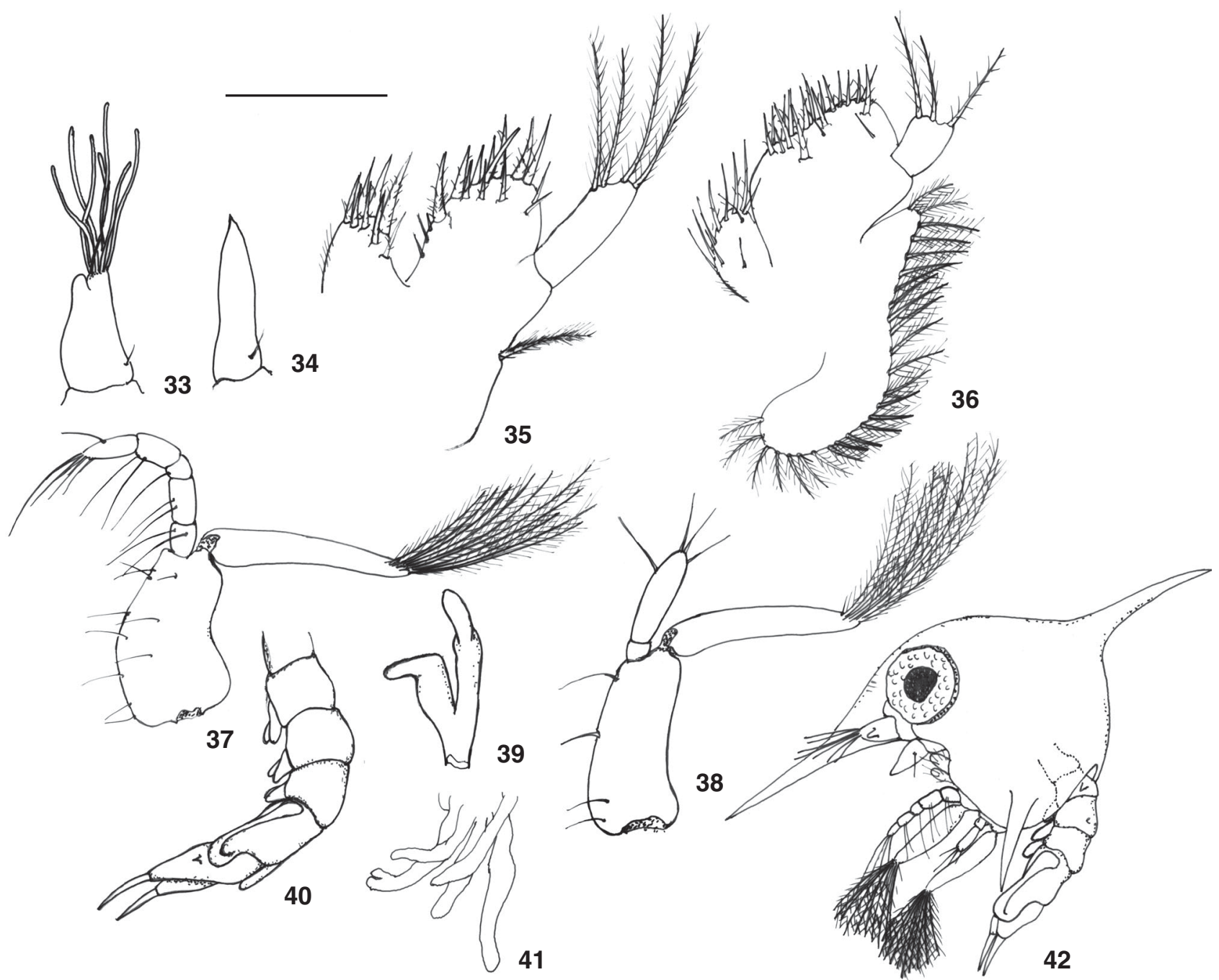

Figure 33-42. Zoea V of Pinnixa gracilipes: (33) antennule; (34) antenna; (35) maxillule; (36) maxilla; (37) first maxilliped; (38) second maxilliped; (39) third maxilliped; (40) abdomen and telson; (41) pereiopods; (42) zoea V, lateral view. Scale bar: $33-34=0.24 \mathrm{~mm}$; $35-$ $36=0.15 \mathrm{~mm} ; 37-38=0.25 \mathrm{~mm} ; 39=0.075 \mathrm{~mm} ; 40=0,36 \mathrm{~mm} ; 41=0,085 \mathrm{~mm} ; 42=0.73 \mathrm{~mm}$.

Third Maxilliped (Fig. 49): completely developed. Basipodite with seven small setae. Endopod 4-segmented with 8, 6, 6,7 setae, respectively. Exopodite 2-segmented, proximal segment with one simple setae, distal segment with four plumose setae.

Pereiopods (Fig. 51): developed, covered with numerous plumose setae, and functional for walking and possibly free-living in water. Chelipeds symmetric bearing small setae and with propodus longer than other segments. Pereiopods (P2-P3) similar in structure. Pereiopod (P4) longer and stronger than others.

Abdomen and telson (Fig. 50): additional somite 6 bearing two simple setae. Other somites bearing additional simple setae dorsally as illustrated. Telson semi-circular, wider than long, posterior margin slightly convex with numerous small setae.

\section{DISCUSSION}

The larval descriptions of pinnotherids are available for 46 species among 15 genera. But, the complete developments of these larvae are recorded only for 26 species. The remaining publications provide only partial information mostly restricted to the first zoea (MARQues \& PoHLe 1996a).

Descriptive studies of the Pinnixa larvae have been carried out in the last years. The results have contributed to improve researches on the plankton collection. These studies have improved the classification of Pinnotheridae, mainly in the morphological aspects. The number of zoeal stages within the Pinnotheridae varies from only one, for Epulotheres Manni, 1993 (Goodbody 1960) to five stages in several genera, such as 


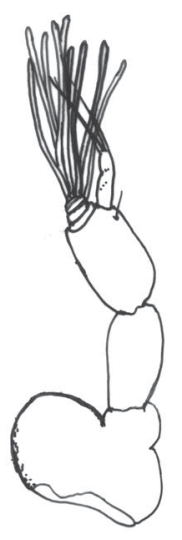

43

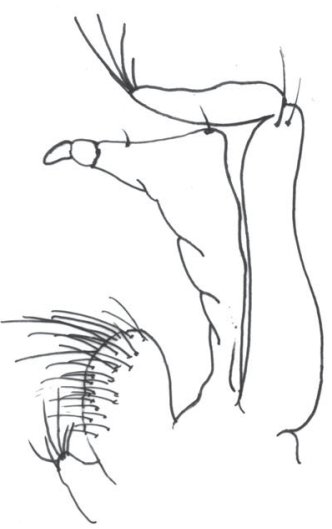

47

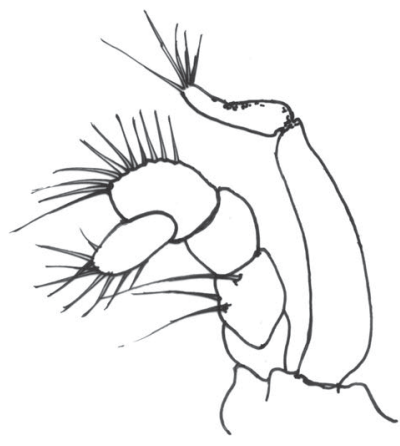

48

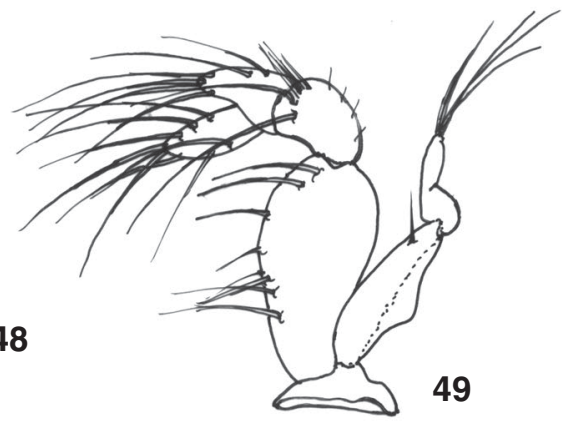

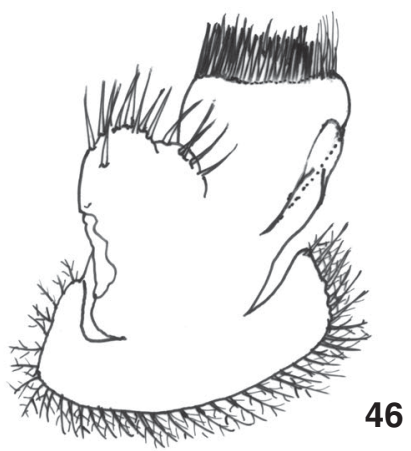

45
46

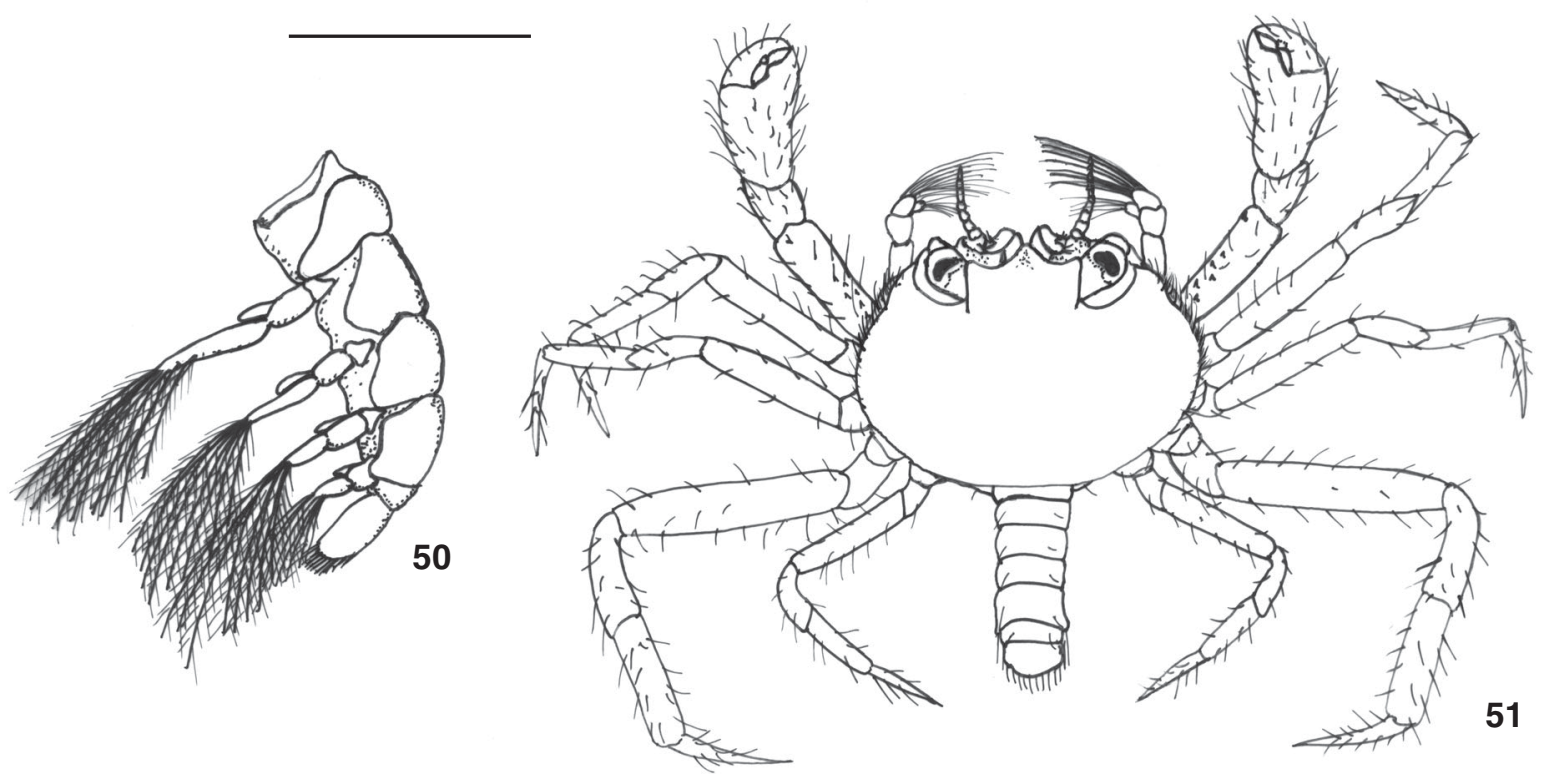

Figures 43-51. Megalopa of Pinnixa gracilipes: (43) antennule; (44) antenna; (45) maxillule; (46) maxilla; (47) first maxilliped; (48) second maxilliped; (49) third maxilliped; (50) abdomen and telson; (51) megalopa, dorsal view. Scale bar: 43-44 = 0.5 mm; $45-46=$ $0.24 \mathrm{~mm} ; 47-49=0.33 \mathrm{~mm} ; 50=0.46 \mathrm{~mm} ; 51=0.96 \mathrm{~mm}$. 
Dissodactylus, Pinnixa and Pinnotheres Latreille, 1802 (Marques \& Pohle 1995).

The morphology of the genera Pinnixa can be distinguished easily within of the family Pinnotheridae due to presence of a structural enlargement of the fifth abdominal segment. This appears to be a distinct characteristic of this genus, as observed in P. longipes (Bousquette 1980), P. rathbuni (SEKIGUCHI 1978 ) and in $P$. gracilipes in the present study.

Abdomen and carapace of $P$. gracilipes showed few changes during zoeal stages. Only the first zoea stage had telson with spines absent and second to fifth zoeal stages showed a pair of spines projected laterally (Fig. 16). These spines appear to be unique for $P$. gracilipes and, they are not present in $P$. longipes not in $P$. rathbuni. Other morphological feature showed only for $P$. gracilipes is the shape of final portion of scaphognathite of zoea I, which is tapering to sharp in P. longipes and $P$. rathbuni but visible rounded in $P$. gracilipes (Fig. 4).

Besides the morphologic differences, other characteristics can distinguish $P$. longipes and $P$. rathbuni from $P$. gracilipes. The larval rearing time averaged 24 days in $P$. gracilipes while, $P$. longipes 26 days. The intermolting period was shorter in $P$. gracilipes than $P$. longipes. Unfortunately, information on larval period was not mentioned by SEKIGUCHI (1978) for P. rathbuni. Similarity is found in the number of larval stages; P. rathbuni, $P$. longipes and $P$. gracilipes have five zoeal stages.

The gross morphology of zoea stages is very similar in $P$. longipes, $P$. rathbuni and $P$. gracilipes but some differences are found between these species. The zoea IV of $P$. gracilipes shows morphological differences in relation to the other two species, mainly in the appendages, the antenna, maxillule and maxilla (Tab. II). Other evident difference observed for $P$. gracilipes in the absence of antennal protopodite in the zoea $\mathrm{V}$, whereas in $P$. longipes this process is larger than endopodite. The protopodite in $P$. rathbuni is smaller than endopodite. These characteristics intensify the morphological divergence of zoeal stages among Pinnixa species.

The megalopa stage of $P$. longipes, $P$. rathbuni and $P$. gracilipes showed similarity. The megalopa of $P$. gracilipes can be easily distinguished from other species through the following morphologic characteristics: triangular rostrum separating the stalked eyes, 10-segmented antenna, fine and long pereiopods, and semi-circular carapace. On the other hand, P. longipes shows rectangular rostrum separating the eyes, 7-segmented antenna, strong pereiopods and semi-rectangular carapace. $P$. rathbuni has a set of large spines on each antero-lateral margin of carapace, a specific character for this species.

The descriptions in the present study are sufficient to distinguish $P$. gracilipes larvae from other described pinnotherids. However, further larval studies are needed to increase the understanding of this taxonomic group.

\section{ACKNOWLEDGMENTS}

To the Instituto do Milênio and to the project Management and Dynamics of Mangrove (MADAM) for the financial support destined to this research; To the Universidade Federal do Pará and Maria Iracilda Sampaio, Laboratory of Molecular Biology of University campus of Bragança, Pará.

\section{REFERENCES}

Alves, E.S. \& P.R. Pezzuto. 1997. Population dynamics of Pinnixa patagoniensis Rathbun, 1918 (Brachyura: Pinnotheridae) a symbiotic crab of Sergio mirim (Thalassinidea: Callianassidae) in Cassino Beach, southern Brazil. Marine Ecology, Berlin, 19 (1): 37-51.

Alves, E.S. \& P.R. PezzuTo. 1998. Dispersão de Pinnixa patagoniensis Rathbun, 1918 (Brachyura: Pinnotheridae) no médio litoral do Cassino, RS, Brasil. Atlântica, Rio Grande, 20: 5-2.

Bousquette, G.D. 1980. The larval development of Pinnixa longipes (Lockington, 1877) (Brachyura: Pinnotheridae), reared in the Laboratory. Biological Bulletin, Miami, 159: 592-605.

Campos, E. 2002. Two new genera of pinnotherid crabs from the tropical eastern Pacific (Decapoda: Brachyura: Pinnotheridae). Journal of Crustacean Biology, Lawrence, 22(2): 328336.

Coelho, P. A. 1997. Revisão do gênero Pinnixa White, 1846, no Brasil (Crustacea: Decapoda: Pinnotheridae). Trabalhos Oceanográficos da Universidade Federal de Pernambuco, Recife, 25: 163-193.

FAxon, W. 1879. On some young in the development of Hippa, Porcellana and Pinnixa. Bulletin of the Museum of Comparative Zoology, Harvard, 5: 253-268.

Goodbody, I. 1960. Abbreviated development in a pinnotherid crab. Nature, London, 185: 704-705.

Grove, M.W. \& S.A. Woodin. 1996. Conspecific Recognition and host choice in a pea crab, Pinnixa chaetopterana (Brachyura: Pinnotheridae). The Biological Bulletin, Massachusetts, 190: 359-366.

Magalhães, C. \& N. Medeiros. 1998. The larval development of palaemonid shrimps from the Amazon Region reared in the Laboratory. VII. Abbreviated development of Pseudopalaemon amazonensis Ramos-Porto, 1979 (Crustacea: Decapoda: Caridea). Acta Amazônica, Manaus, 28 (4): 433-448.

Marques, F. \& G. Poole. 1995. Phylogenetic analysis of the Pinnotheridae (Crustacea, Brachyura) based on larval morphology, with emphasis on the Dissodactylus species complex. Zoologica Scripta, Oslo, 24 (4): 347-364.

Marques, F. \& G. Pohle. 1996a. Laboratory-reared larval stages of Dissodactylus mellitae (Decapoda: Brachyura: Pinnotheridae) and developmental patterns within the Dissodactylus species complex. Canadian Journal of Zoology, Canada, 74: 47-62.

Marques, F. \& G. Pohle. 1996b. Complete larval development of Clypeasterophilus stebbing (Decapoda: Brachyura: Pinnotheridae) and a comparison with other species within the Dissodactylus complex. Bulletin of Marine Science, Miami, 58 (1): 165-185.

Pereyra Lago, R. 1987. Larval development of Sesarma catenata 
Ortmann (Brachyura: Grapsidae: Sesarminae) reared in the laboratory. South African Journal of Zoology, Grahamstown, 22 (3): 200-212.

Pereyra Lago, R. 1989. The larval development of the red mangrove crab Sesarma meinerti Ortmann (Brachyura:
Grapsidae) reared in the laboratory. South African Journal of Zoology, Grahamstown, 24 (3): 199-211.

Sekiguchi, H. 1978. Larvae of a pinnotherid crab, Pinnixa rathbuni Sakai. Proceeding of the Japanese Society of Systematic Zoology, Tsu, 15: 36-46.

Received in 14.VII.2005; accepted in 10.V.2006. 